\title{
Linguistics and the intellectual challenge of diversity
}

\author{
The case of India
}

\begin{abstract}
The status of modern linguistics within the modern disciplinary order is unclear, as it is neither a recognizable natural science, nor primarily a hermeneutic, interpretative discipline. In seeking to understand the intellectual history of colonial linguistics and its impact on polities such as India, this ambiguous status is a complicating factor, in particular when we confront questions of universalism, cultural difference, and identity politics. The key concept in this history is 'Aryan'. The intellectual confidence with which nineteenth century comparativism sought to map the world's languages, races, and cultures has largely disappeared, under assault from a range of ideological and intellectual opponents. In particular, the racial model of Indian civilization, reflected in Herbert Risley's reading of a bas-relief at Sanchi, has been completely discredited. Yet colonial linguistics, which had arguably a much greater and more long-lasting impact on India, remains largely unchallenged, with the exception of critics associated with Hindu fundamentalism. For these critics, the distinctions drawn within colonial linguistics led to a schism within Indian society, by conceptualizing a historical divide between invading Aryans and indigenous Dravidians. A set of difficult questions arise from this. On the one hand, the rejection of western science is today linked to Hindu fundamentalism, and is driven by a xenophobic form of cultural relativism; on the other, linguistics is not a science in any universal sense, and its role in creating divisions in Indian society has arguably been a highly destructive one.
\end{abstract}

Keywords: linguistics; race theory; comparativism; Aryanism; universalism; romantic particularism; Sanchi bas-relief; Hindu fundamentalism; Western science

\section{Introduction}

In institutional terms, one might argue, we remain in the late nineteenth century. The nineteenth century gave us the modern professionalized disciplines with which the globalized university functions today, in particular the academic divi-

Christopher M. Hutton, University of Hong Kong

2 Open Access. ( 2021 Christopher M. Hutton (c) BY-NC-ND This work is licensed under a Creative Commons Attribution-NonCommercial-No-Derivatives 4.0 License.

https://doi.org/10.1515/9783110691504-006 
sion of labour between science and humanities, and the insistence on the need for the appropriate methodology for the particular intellectual task or object of study. While the modern natural sciences have been subject to a range of attacks, as has modern institutionalized medicine, from postmodernists in particular, their dominance in the modern university is today largely unchallenged. The humanities by contrast are facing a range of fundamental challenges in increasingly managerial (or neoliberal) university systems, suffering a loss of certainty in matters of methodology and academic standards, and at the same time struggling to meet the demand for social impact and policy relevance.

The discipline of linguistics has operated as a universalistic framework for confronting the nature of human linguistic difference. It is universalistic in that it represents itself as a method for describing and analysing the structure of any known language; within that, the discipline has moved between universalism and relativism, but its relativism has always been contained within the scientistic framework as regards methodology. In this it has been aided by the powerful universalistic representational system of alphabetic writing and its off-shoots, such as the International Phonetic Alphabet (see Jones 1789; Kelly 1981). The historiography of linguistics identifies two founding texts, namely Bopp (1816) and Saussure (1972 [1916]). The first represented the attempt to grasp languages as historically embedded objects, the task of the scholar being to identify the interrelationships between languages and track their changes at as high a level of precision as possible. The second gave primacy to the synchronic langue as an autonomous, ahistorical system, each incommensurable with other systems. The century between Bopp and Saussure saw the rise of professionalized natural science, which put pressure on the biological terms used in linguistics, transforming them gradually into metaphors. Saussure's Cours de linguistique générale gave the study of language special status, in that it denied that there was an empirical object of study given in advance:

D’autres sciences opèrent sur des objets donnés d'avance et qu'on peut considérer ensuite à différents points de vue; dans notre domaine, rien de semblable. [...]. Bien loin que l'objet précède le point de vue, on dirait que c'est le point de vue qui crée l'objet (1972 [1916], 23).

This is a very strange statement if it is read as coming from the founder of a scientific discipline. Linguistics belongs at best to the anxious centre ground between natural sciences and humanities, along with psychology and economics. It is neither a recognizable natural science, nor an avowedly hermeneutic discipline.

The focus of this discussion is India, since today in Indian cultural politics the question of linguistics, in particular the legacy of colonial scholarship, remains a highly contentious one. Aryanism, a key product of colonial scholarship, was articulated through a range of disciplinary modes, with the analysis of texts, 
ancient monuments and artefacts, contemporary or near-contemporary linguistic evidence, contemporary cultural beliefs and material practices, and racial analysis (anthropometry). In a complicated and uneven circularity, conclusions from one mode were used to support or undermine those from another, running alongside arguments about the evidential priority of one mode over another. Today, debates around Aryanism in contemporary India raise questions of universal values and cultural relativism, the status of Western scholarship together with its methodological and intellectual presuppositions, and the link between anti-colonial polemics and fundamentalist identity politics.

\section{Enlightened universalism versus Romantic particularism}

The tensions between universalism and particularism as a modern dilemma are, arguably, first identifiable in the works of Johann Gottfried Herder. Herder struggled to do justice to particularity, to the principle that "one epoch should not be judged by the standard of another" (Evrigenis and Pellerin 2004, xxvi), in an authentically modern reflexivity:

No one in the world feels the weakness of general characterization more than I. One paints an entire people, age, part of the earth - whom has one painted? One captures successive peoples and times in an eternal alternation, like waves of the sea - whom has one painted? Whom has the describing word depicted? In the end, one summarizes them in Nothing, as a general word, when everyone perhaps thinks and feels what he will - flawed means of description! How one can be misunderstood! (Evrigenis and Pellerin 2004, 23). ${ }^{1}$

To take this view, on the one hand, whilst seeing human history as governed by divine providence, seems characteristically modern in its attempt to recognize difference, whilst maintaining a moral framework for judgment. The division of the world into peoples or Völker is for Herder in some sense natural, or at least more natural than the division into states, yet humanity is one. Herder was suspicious

1 [Niemand in der Welt fühlt die Schwäche des allgemeinen Charakterisirens mehr als ich. Man mahlet ein ganzes Volk, Zeitalter, Erdstrich - wen hat man gemahlt? Man fasset auf einander folgende Völker und Zeitläufte, in einer ewigen Abwechslung, wie Wogen des Meeres zufammen wen hat man gemahlt? wen hat das schildernde Wort getroffen? - Endlich man fasst sie doch in Nichts, als ein allgemeines Wort zusammen, wo jeder vielleicht denkt und fühlt, was er will - unvollkommenes Mittel der Schilderung! wie kann man missverftanden werden! -] (Herder 1774, 44). 
of what we today might call the reification of culture: "Nothing is more ill-defined than this word and nothing is more misleading than the application of this word to whole peoples and epochs."2

The Napoleonic invasions on the German territories resonate to this day, having the effect of polarizing the internal tensions found within Herder's writings into a French-German duality, into two ideal types or stereotypes. A militant Republican universalism with a civilizing mission broke into a confederation of feudal states, accelerating a process of imagining the German nation as single and undivided (Horn 2010). One response to this was Johann Wolfgang von Goethe's in his Hermann und Dorothea (1797), where the assertions of possession and ownership are reactive. Fichte's Reden an die deutsche Nation (1808), based on lectures held in Berlin during the winter of 1807-1808, while Napoleon's army was occupying the city, represents the first anti-colonial assertion of linguistic and cultural autonomy, in that it was directed at a specifically and self-consciously modernizing form of conquest.

The German case thus became the prototype of the dilemma of the colonized, namely the psychological and political consequences of the imposition of modern rights and freedoms by military force and occupation, coupled with the usurpation of pre-existing institutions, and manifest shortcomings in the fulfilment of modernity's promises. One could also see this modernity as having first colonized the feudal state of France, through a process of violent levelling and centralization, sweeping away the internal institutional order and embedding a distrust of regional linguistic and customary forms. Modernity, revolution, and empire are thus intertwined, as the cases of the German states, Haiti (invaded by Napoleonic forces in 1802) and Egypt and Syria (campaign in the Ottoman territories, 17981801) make clear (Messling 2019).

In effect the internal tensions and contradictions of Herder's work were separated into two ideal types (Enlightenment versus Romanticism, universalism versus relativism, and similar binaries). Universalism has been tainted by its association with colonialism and imperialism, while particularism has been expressed in the form of radical nationalism and fascism. The result is that there are widely divergent readings of Herder's place in the lineage of European ideas (Zammito et al. 2010).

2 [Nichts ist unbestimmter als dieses Wort und nichts ist trüglicher als die Anwendung desselben auf ganze Völker und Zeiten] (Herder 1784, I: 2). 


\section{Comparativism and Aryanism}

One way to understand the position of the humanities today is that extreme reflexivity has replaced the methodological confidence of the late nineteenth century philological disciplines and comparativism in particular. Comparativism has deep intellectual roots in the Western tradition (de Mauro and Formigari 1990). It is based on the assumption that humanity moves from unity to diversity, and that time erases or blurs the boundaries between original types. The classic universalist position is that humanity was in its origin one pair, in the figures of Adam and Eve, and the fall from that original state into historical time displaced that unity both in space (the expulsion from Eden) and in unity (the story of Cain and Abel). The flood and the subsequent resettlement of the earth by the sons of Noah suggest a natural ordering of the newly emergent diversity: "By these were the isles of the Gentiles divided in their lands; every one after his tongue, after their families, in their nations" (Genesis 10: 5). Yet in Genesis 11: 1 we read: "And the whole earth was of one language, and of one speech". The confusion at Babel represents a further point of origin, with diversity associated with punishment, displacement, and disunity.

The relationship of human diversity to time and space (place) is a complex and contested chapter of intellectual history. If time is decay, then diversity is a fall from universality; but if time passing sees the unfolding of authentic essences, then in diversity is found emergent self-realization. If the passage of time corresponds to human progress, then human diversity is marked by difference along the continuum of development, as in the relation of children of different ages to the adult (Schiller 1789, 11). If that diversity is contingent rather than biological, then humankind may be reunited at some future point within a shared enlightened world order. Secular understandings of history may have a teleology (Hegel, Marx) or an end (Fukayama), just as religious ones (Christianity). Globalisation is seen by some as a threat to a world ecology of difference, erasing boundaries between human types and eradicating local understandings and practices. Yet history may have no direction at all, as in modern systems theory (Saussure, Luhmann).

Max Müller found in comparativism a way of both recognizing the diversity of human languages and cultures, but also accommodating this within a universal frame. He found in contemporary scholarship the danger of "extreme specialisation" which threatened the work of synthesis required to grasp the grander narrative: "all special knowledge, to keep it from stagnation, must have an outlet into the general knowledge of the world" (1881 [1874], 4). The comparative method represented for Müller the completion of the intellectual journey that had begun with 
Sir William Jones and Henry Thomas Colebrooke. Now, with philological rigour, with the "throroughness, minuteness, and critical accuracy" (1881 [1874], 9) of traditional classical studies, it was possible to make more authoritative assertions than previously. In this way it had been demonstrated that "in language, and in all that is implied by language, India and Europe are one” (1881 [1874], 9).

The sense that the diversities of the world's languages and peoples could be brought together within a single, multi-disciplinary enterprise fuelled an expansive vision of intellectual progress. The study of the languages and cultures of the East had taught the Europeans "that there are other worlds beside our own, that there are other religions, and that the history of philosophy from Thales to Hegel is not the whole history of human thought" (1881 [1874], 11). At the most basic level, the repetition of any fact or phenomenon was "the first step" in that "wonderful process of generalisation" which was the foundation of "all intellectual knowledge and of all intellectual languages" (1881 [1874], 12). The basic recognition of identity underlay the comparative method, "the highest kind of knowledge in every science" (1881 [1874], 12).

Müller's work is characterized by three tendencies in conflict: firstly, the celebration of a kind of methodological objectivity, what might be termed a pure philology, a scholarly position from which the world's diversity could be mapped out in its core relationships and chronologies created of myths, migrations, and texts. Linguistics was a more objective and reliable guide to prehistory than its rivals. The science of comparativism suggested an objective, bird's eye view of human history, where the method penetrated beneath the visible surface to undo, in the abstract, the effects of time and change. Secondly, Müller celebrated Aryanism as the ideal brotherhood of East and West, a sentiment reflected in the inscription in the former Indian Institute at Oxford University which proclaimed that the building was for the use of "Āryas (Indians and Englishmen)" (see Leopold 1974, 584fn.). Finally, there was Müller’s commitment to Christianity.

In contrast to Christianity, Aryanism took a partial or particularist view, focussing not on the original homeland of humanity and the Adamic language, but on the homeland of the Aryans and the original Aryan tongue. Christianity is universalist, but it emerged from, in Müller's terms, the Semitic world. At this level there exists a direct contradiction between Aryanism and Christianity, not just for Müller, but for the increasingly nationalistic or particularistic forms of Protestant Christianity. This was ultimately expressed in a set of radical attempts to separate Jesus and Christianity from Judaism (see Heschel 2008). Müller had failed to be appointed to the Boden Chair of Sanskrit at the University of Oxford on account of a perception that he was a less than orthodox Christian (Chaudhuri 1974, 223). Müller however denied that he was hostile to missionaries (1881 [1874], 12): "I have lately incurred very severe obloquy for my supposed hostility to missionary enter- 
prise. All I can say is, I wish that there were ten missionaries for every one we have now." Commenting on a study by the Dean of St Paul's, Richard William Church, The Sacred Poetry of Early Religions, which had concluded that the Psalms were superior to the Vedic hymns (Church 1874), Müller responded that this was no doubt true, "from the point of view he has chosen", but the principle value of the Vedic hymns lay "in the fact that they are so different from the Psalms, or, if you like, that they are so inferior to the Psalms" (1881 [1874], 38). Yet they had another quality (1881 [1874]: 38): “They are Aryan, the Psalms, Semitic; they belong to a primitive and rude state of society, the Psalms, at least most of them, are contemporaneous with or even later than the heydays of the Jewish monarchy." What was valuable was not their sophistication or polish of the Veda, but, contrary to expectations, its raw vitality. It was worth excavating this text because:

it stands alone by itself, and reveals to us the earliest gems of religious thought, such as they really were; it is because its poetry is what you may call savage, uncouth, rude, horrible it is for that very reason that it was worthwhile to dig and dig till the old buried city was recovered, showing us what man was, what we were, before we had reached the level of David, the level of Homer, the level of Zoroaster, showing us the every cradle of our thoughts, our words, our deeds (1881 [1874], 39).

Müller ended with an ecstatic reading of an extract from a Vedic hymn, one that celebrated unity in worship, declaiming "verses which thousands of years ago may have been addressed to a similar meeting of Aryan fellow-men" (1881 [1874], 39-40).

Beneath the universalism lies an ugly proto-fascistic relativism, an affective identification with Aryans from the distant past. This stands in stark contrast to the claimed objectivity of method that comparativism represented, as well as to the spiritual universalism of Christianity.

\section{The Sanchi bas-relief}

In 1854, the archeologist Major Alexander Cunningham of the Bengal Engineers published a study of the Buddhist stupas or topes of Central India, including the Sanchi complex. This complex is located in the state of Madhya Pradesh, northeast of Bhopal, and in its origins dates from the $3^{\text {rd }}$ century BCE, following a commission by the emperor Ashoka. In the colonial context, the existence of the complex had first been reported by General Henry Taylor (1784-1876) in 1818 and it was subsequently described by Captain Edward Fell (Fell 1819; Guha-Thakurta 2013). A tope is "a solid hemispherical building" playing the role of "a religious edifice 
dedicated emphatically to the Buddha" (Cunningham 1852, 109). Cunningham described one bas-relief scene as follows:

Adoration of Trees. - Three trees, that to the left with an altar. Two females and a child kneeling between the trees. To the front, two royal personages with hands joined in adoration, and two females with offerings. In the foreground two monkeys, one with a cup $(1854,231)$.

This panel is on the northern gateway, west pillar, east face (Dhavalikar 2003, 60-61). The underlying framework animating Cunningham's investigations was a form of primitive Aryanism, involving belief in a "more ancient Buddhism, which prevailed not only in India, but in all the countries populated by the Aryan race" (1854, vi-vii). Hence the Buddhist worship of trees, found in the Sanchi monuments, was "the counterpart of the Druidical and adopted English reverence for the Oak" $(1854, v)$. Cunningham's contemporary and rival Frederick Maisey described the compartment as showing "two men, four women, and a child, in Indian dress, and two large apes offering worship to a tree and altar, between two other trees" (1892, 31). Maisey also produced a sketch of the panel (see Fig. 1). Like Cunningham, Maisey assumed an original Aryan people located in Central Asia which divided initially into "the Iranian or Persian, and Indian branches" (1892, 99).

The architectural historian James Fergusson likewise saw in the image a representation of tree worship, but found it "remarkable because the two principal devotees are monkeys" (Fergusson 1868, 117). He rejected the idea that the monuments were an expression of Aryanism. Fergusson evoked a lost shared mythol-

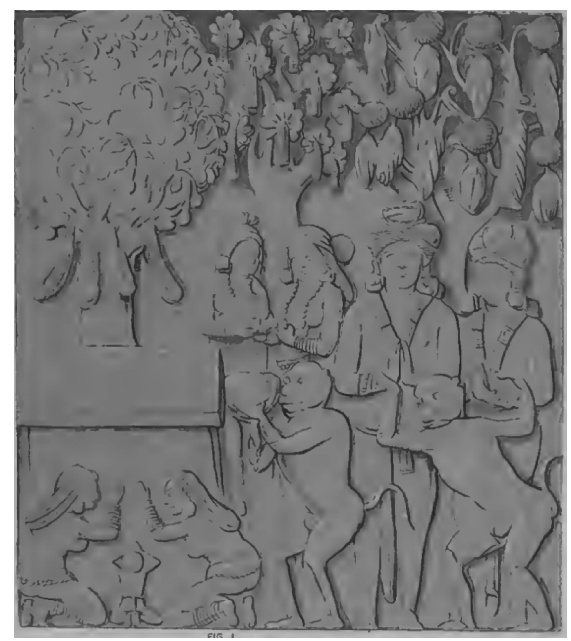

Fig. 1: Maisey's sketch of the Sanchi bas-relief (Maisey 1892, plate ix). 
ogy from "an early stage of human civilization" in which serpent and tree worship played an important role $(1868,1)$. In the case of trees:

With all their poetry, and all their usefulness, we can hardly feel astonished that the primitive races of mankind should have considered trees as the choicest gift of the gods to men, and should have believed that then spirits still delighted to dwell among their branches, or spoke oracles through the rustling of their leaves $(1868,1-2)$.

The question was how to understand the racial underpinnings of Buddhism, and of the Sanchi complex in particular, given the assumption that no Aryan race, "while existing in anything like purity, was ever converted to Buddhism, or could permanently adopt its doctrines”. Fergusson's tentative conclusion from a racial reading is that:

\begin{abstract}
the people who are associated with Buddha in both Topes [Sanchi and Amravati] are the mixed race of Bengal, - a people with a certain infusion of Aryan blood in their veins, but which had become so impure from mixture with that of the aboriginal tribes who existed in Bengal before the Aryan immigration, that the distinctive features of their higher civilization were almost entirely lost $(1868,225)$.
\end{abstract}

A much inferior indigenous population (termed Dasyus) was conquered by the numerically tiny but greatly superior Aryans, who then were weakened by subsequent "less pure or Turanian races" (1899: 37), leading to the eclipse of pure Vedic religion. For Fergusson, the materiality of built monuments was inferior to the creation of texts: "all that written in India that is worth reading was written by Aryans; all that was built was built by the Turanians, who wrote practically nothing" $(1899,38)$. In commentary the reverend Samuel Beal politely questioned whether the trees were "objects of worship" in the sense that Fergusson seems to have understood: "the Tree in the eyes of the Buddhist was a 'sacred tree', but he did not worship it" $(1870,6)$. Beal gave a straight Buddhist reading of the panel as depicting "the legend of the monkeys, who took the pâtra [alms bowl] of Buddha and filled it with honey, and then brought it to Buddha" $(1870,18)$.

\title{
Herbert Risley's analysis
}

One of the most detailed analyses of this bas-relief is that by Herbert Risley (18511911), the colonial official and ethnographer in charge of the 1901 Indian census:

Under trees with conventional foliage and fruits, three women, attired in tight clothing without skirts, kneel in prayer before a small shrine or altar. In the foreground, the leader of a procession of monkeys bears in both hands a bowl of liquid and stoops to offer it to the 
shrine. His solemn countenance and the grotesquely adoring gestures of his comrades seem intended to express reverence and humility. In the background four stately figures - two men and two women - of tall stature and regular features, clothed in flowing robes and wearing most elaborate turbans, look on with apparent approval at this remarkable act of worship (Risley 1891, i).

Previous "antiquarian speculation" had either ignored this image or "sought to associate it with some pious legend of the life of Buddha" (1891, i). By contrast Risley found in the image $(1891,1)$ "the sculptured expression of the race sentiment of the Aryans towards the Dravidians, which runs through the whole course of Indian tradition and survives in barely abated strength at the present day". This was reminiscent of the narrative in the Ramayana and the army of apes that "assisted Rama in the invasion of Ceylon":

It shows us the higher race on friendly terms with the lower, but keenly conscious if the essential difference of type and not taking part in the ceremony at which they appear as patronizing spectators $(1891,1)$.

The sculpture reflected a racial belief which "far from being a figment of the intolerant pride of the Brahman, rests upon a foundation of fact which scientific method confirm, that it has shaped the intricate groupings of the Caste system, and has preserved the Aryan type in comparative purity throughout Northern India” (1891, i-ii).

The discussion first appeared in an article entitled "The race basis of Indian political movements" (1890), and the image later appeared on the cover of Risley's The People of India, where the discussion was repeated (1908, 4-5). Ripley's analysis of the bas relief was preliminary to his discussion of the background to the census of Bengal. Risley pointed to the dynamics of change in contemporary India, with the primitive races being Brahmanized, i.e. absorbed into Hinduism by the applications of fictions of ancestry, and at the same time Hinduism itself becoming less clearly defined: "the opening of communications, the increase in the facilities for travel, and the spread of education, are tending to obliterate the land-marks of the Hindu faith, to slacken the bonds of caste, and to provide occupations unknown to the ancient polity" (1891, iii). While these processes had been going to a degree for many centuries, one could still make a "fair guess at a man's caste from his personal appearance" (1891, xix). The study of physical types would allow the observer to "detach considerable masses of non-Aryans from the general body of Hindus" and to identify the as far as possible the original stock such as "Dravidian, Lohitic, Tibetan, and the like" (1891, xix). In Europe where "the crossing of races constantly obscures their true affinities", the use of statistical analysis had shed light on "the distribution of different race stocks in the 
population”. In Bengal, where the situation was much clearer, since the mount of crossing was comparatively small, an analysis would "enable us to determine the divergence of each of these aggregates from known Aryan or non-Aryan types" (1891, xx). This would "be regarded with approval by the leaders of Hindu community in all parts of Bengal, among whom both the orthodox and the advances lay considerable stress upon the purity of their descent", as well as to scientists in Europe (1891, xx).

Risley (1891, xx-xxii) cited a long extract from J. C. Nesfield's Brief View of the Caste System of the North-Western Provinces and Oudh (1885), where caste was presented as deriving from "community of function". Nesfield argued that the division of the contemporary population of India into Aryan and aboriginal was false, and his theory of caste necessarily implied "the unity of the Indian race" (1885, 3). While accepting the narrative of invasion by a race of "white-complexioned foreigners" into the Indus valley four thousand years ago, the theory "nevertheless maintains that the blood imported by this foreign race became gradually absorbed into the indigenous, the less yielding to the greater, so that all traces of the conquering race eventually disappeared" $(1885,4)$. The Aryan invaders had been absorbed and "there was no real difference of blood" $(1885,4)$. The "physiological resemblance" that existed across all strata of Indian society was "an irrefragable proof that no clearly defined racial distinction has survived". This evidence was superior to linguistic evidence "on which so many fanciful theories of ethnology haven been lately founded":

Language is no test of race; and the question of caste is not one of race at all, but of culture. Nothing has tended to complicate the subject of caste so much as this intrusion of a philological theory, which within its own province is one of the most interesting discoveries of modern times, into a field of inquiry with which it has no connection (Nesfield 1885, 4).

Risley however rejected Nesfield's assertion that there were no racial differences to be observed among contemporary Indians, and argued that anthropometric methods could potentially show "marked differences of type" (1891, xxiii). Anthropometry was a science which sought by measurement of key physical attributes 'to ascertain and classify the chief types of mankind, and eventually by analyzing their points of agreement and difference to work back to the probable origin of the various race-stocks now traceable' (1891, xxvi). India, with its rules against exogamy whereby it was "forbidden by an inexorable social law to marry outside of the group to which they themselves belong" and there was "pride of blood and the idea of social purity" (1891, xxvii). In Europe, by contrast, anthropometry was faced with "the constant intermixture of races which tends to obscure and confuse the data arrived at by measurement" (1891, xxvii). In India, while there were "levelling and centralizing forces", nonetheless the "race element remains, for the 
most part, untouched" and so for an informed observer "the personal appearance of most Hindus gives a fairly accurate clue to their caste" (1891, xxx).

Risley's use of this image to support his views on the racial basis of caste was rejected by the official in charge of the Punjab census, Harikishan Kaul. The panel was "not intended to exhibit anything like social distinction or superiority" and as a Buddhist sculpture would have had no relationship to the Ramayana (Kaul 1912: 400). Kaul took issue with the reading of the clothing as "tight", and insisted that the double figure of the monkey was "intended to signify motion":

The monkey is offering a bowl of honey according to the famous Budhistic story. The date of the carving [...] is about 100 B.C. and in all Budhistic sculptures of that period, it was customary not to show Budha himself, but to depict the Bodhi tree or manda or some other Chinha (mark) as the sacred object which would be worshipped as an emblem of Budha $(1912,400)$.

The figures kneeling at the front were not much larger than those standing, but the standing figures were depicted as close to the sculptor's position:

The variation in size thus obviously indicates distance, and in determining the sizes, the sculptor appears to have placed himself farthest away from the manda, which is the most important point in the picture. It is wonderful, indeed, how a simple religious picture, having nothing whatever to do with race, can, with the best of intentions, come to be adopted as an unquestionable basis of a theory of the origin of caste $(1912,400)$.

Risley's narrative of race was problematic, not least because terms like race, tribe, and caste were extremely vague when applied to the Punjab or indeed India in general: "There is apparently no equivalent for race in the India vernaculars" (Kaul 1912, 400). The principles of common descent and endogamy which Risley applied to caste were in contradiction: "people descended from a common ancestor, however distant, cannot intermarry according to the first principles of caste" (1912, 401). Caste was a foreign term "applied to a complicated Indian institution" (1912, 401). Reviewing the "burning question" of whether "the basis of caste is racial or functional", Kaul expressed doubt that the Aryans had been a race: "The oldest authority on the subject are the Vedas, and as far as I can see, the term Arya is used there not in a racial sense" $(1912,404)$. While there might have been "an Aryan and a Dravidian race", but the term Arya was not used in this sense, but rather as "a distinction of merit" (1912, 404).

Risley's reading of the bas-relief is an obvious target for postcolonial critique. Dirks (2001, 213) comments: "So for Risley, the judgment of science confirmed the attitude of the Brahman; so for Risley race history, and perhaps as importantly race sentiment, were the keys to understanding caste". Smith $(2003,54)$ is even more dismissive: "Through ignorance of the basic conventions of Buddhist art, 
Risley sees only a primitive ritual devoid of point carried out by a subhuman no better than a monkey. He sees the demi-god yakșas as Aryans and the monkey as a Dravidian!”

The uncontroversial view today is that the Buddhist reading is correct, following the consensus of the colonial scholarship. In Sir John Marshall's A Guide to Sanchi, the panel was described as follows:

The offering of a bowl of honey to the Blessed One by a monkey. Buddha here is represented by his pipal tree and throne, to which devotees are doing obeisance. The figure of the monkey is twice repeated, first with the bowl and then with empty hands after the gift has been made. The incident is portrayed in much the same way on the reliefs of Gandhāra $(1918,58)$.

This was elaborated in Debala Mitra's Sanchi as follows (2001 [1973], 38): “The spontaneous offering of honey to Buddha by a monkey is regarded as one of the eight important events of Buddha's life. This incident is said to have taken place at Vaiśālī”. The Buddha had gone there "in order to relieve the Buddha of a frightful pestilence” (Mitra 1971, 5).

\section{Aryans and Dravidians}

Whereas the racial or ethnic reading of the Sanchi bas-relief, with its obsession with the hierarchy of human types, is now seen as an obvious relic of a particular form of race-obsessed colonial scholarship, the edifice erected by the colonial linguistics remains largely intact. In particular, the Indo-European or Aryan language family which was articulated in the wake of the famous essay by Sir William Jones (1798) remains academic orthodoxy. Yet the impact of the categories set up by colonial linguists was much greater and more long-lasting than any racial reading of Buddhist iconography. As Trautmann writes:

Jones applies the figure of the Tree of Nations directly to language as a model of language history, and by his doing so language history becomes a remedy and substitute for the lost memory of the history of nations. Language, like the DNA in our selves, contains, unknown to its speakers, the hidden history of the human race $(2006,20)$.

Trautmann describes the discovery of the Dravidian language family in terms of the comparative method:

The method of the word list constitutes in its seeming simplicity the first, surgical move of historical linguistics: the cutting away of the later, borrowed, and complex accretions to reveal the native core of language, so that the operation of comparison can be performed on the authentic body of the language $(2006,34)$. 
The effect of this is to reveal the underlying pure types concealed by time, and by borrowing and mixing:

This allows the historical relations among languages to be figured as the eradiating branches of a tree, since the borrowings or mixtures that would make the branches grow into one another have been discarded by analysis. It is well to keep in mind the conception of language that undergirds the genealogies of languages in historical linguistics $(2006,34)$.

The initial observations were made by Francis Whyte Ellis (1816), though the postulated language family became better known through Bishop Robert Caldwell's A Comparative Grammar of the Dravidian or South Indian Languages (1856). Ellis wrote that "neither the Tamil, nor the Telugu, nor any of their cognate dialects are derivations from the Sanscrit" (Ellis, in Campbell 1816, 7). While Sanskrit may have contributed to their "polish", they "form a distinct family of languages, with which the Sanscrit has, in latter times especially, intermixed, but with which it has no radical connexion" (Ellis, in Campbell 1816, 7). Once the accretions from Sanskrit were stripped away, what remained was "the pure native language of the land" which was an autonomous and self-sustaining system in its own right, in that it was "capable of expressing every mental and bodily operation, every possible relation and existent thing; for, with the exception of some religious and technical terms, no word of Sanscrit derivation is necessary to the Telugu" (Ellis, in Campbell 1816, 19).

The model here is of vernacular liberation, with Sanskrit playing an analogous role to Latin in relation to the European languages. In terming the Dravidian languages the pure native languages, the model created a hierarchy of authenticity which reflects the politics both of the Reformation and linguistic nationalism. In its hostility to Sanskrit it inverts the language hierarchy, in a move directly paralleling Protestant hostility to the Chinese writing system. In the nineteenth century, the Chinese characters came under concentrated attack from Protestant missionaries and modernizers for their artificiality and alienation from the natural linguistic medium, namely speech. What had been seen as a universal, lucid, and rational system for representing meaning was now noxious, obscurantist, and elitist, and a symptom of China's enfeeblement and decline (Dyer 1835; Hutton 2007).

Trautmann's view is that the identification of the Dravidian language family was a genuine discovery, since linguistics operates with an objective method, namely comparativism. Whatever one makes of this claim, the Aryan-Dravidian reading of Indian linguistic diversity is no less political than Risley's racial reading of the bas-relief at Sanchi. The methodology employed by Ellis reflects a vernacularist ideology which distinguishes between the organic and the artificial elements of a language system. Its corollary, the Aryan-Dravidian model of Indian 
history, is highly contested, setting up as it did a binary opposition between invader and invaded, conqueror and indigenous:

It has been the serious belief of many scholars, both Eastern and Western, that before the Vedic Aryans had entered into India, it had been inhabited by a race of people called the Dravidian whose culture totally differed from that of the invaders. It is also believed that the Vedic Aryans were so powerful as to occupy the whole of India and supplant the Dravidian culture by their own Vedic and Sanskrit culture. (Shamsashtri 1930, 36)

To simplify, there are today two main strands of opposition to this mainstream invasion model (see Tharpar 1996). The first emphasizes the unity of India and its continuity since ancient times (Talageri 1993; Frawley 2005). The second takes the Aryan invasion to be the foundation of inequality in India today, speaking in terms of Hindu imperialism. The ancient Aryan invasion is therefore as akin to a colonial incursion, so that the British Aryans were just a continuation of previous forms of Aryan domination (Theertha 1941; Biswas 1995).

One militant strand that rejects Aryan invasion theory is associated with Hindutva ideology. In their book, Breaking India (2011), Rajiv Malhotra and Aravindan Neelakandan argue that Dravidian identity politics and the analogy between oppression of the Dalits and other indigenous rights movements reflect malign foreign influence, both historically, through the institutions of colonialism and its scholarship, and in contemporary world, where Islamic radicalism, Marxism, and missionizing by evangelical Christianity all threaten the unity of India. Malhotra and Neelakandan's work is a reflection of an anti-colonial and anti-globalisation position. Malhotra is a critic of Western universalism, seeking in his work Being Different to return the gaze of the West by scrutinizing it from an Indian, "Dharmic", point of view. A particular target of this work is Hegel:

Hegel's theory of history has led to liberal Western supremacy, which hides behind the notion of providing the 'universals'. These European Enlightenment presuppositions became incorporated in the confluence of academic philosophy, philology, social theories and 'scientific' methodologies - all of which were driven by various imperial and colonial values alongside Christian theology $(2011,325)$.

As Malhotra explained:

We know of many universal claims made by Westerners in the past. To give just a few examples: The conquistadors claimed a universal gaze bestowed on them by God with regard to their view of Native Americans. The Europeans claimed to be the keepers of "a shared humanity" in their justification of black slavery, Native American genocide, and Indian colonization. The fascism that emanated from G. W.F. Hegel (and culminated in Hitler's Auschwitz) resulted from his "universalism" and was justified as being in the best interest of the "World Spirit." We have been there before! $(2013,371)$. 
Malhotra's conclusion is that a truly neutral position is not possible, a view he would share with Western proponents of the situated nature of knowledge. Yet we cannot condemn Risley's colonial racism as pseudo-scientific unless we believe in an at least partially context-free scientific epistemology.

\section{Conclusion}

The rejection of the universalistic claims of Western science is fundamental to Hindutva-inspired ideology, a position it shares with postmodern critiques of science in the West. For its critics, science is embedded in its cultural and ideological context, and its universalism is merely blindness to its own conditions of production. The scientific revolution gave rise to the false universal of the distinction between nature and culture (Latour 1991), which in turn led to the intractable division within modernity between natural science and other political and interpretative disciplines.

In a series of polemical works, Meera Nanda has pointed to the parallels and interactions between postmodernism and Hindu fundamentalism. She argues that there is a necessity "to take back science, reason and the values of the Enlightenment from the anti-modernist critics", so as to critique "the deeply antisecular and irrational worldview propagated by Hindutva in the name of 'vedic science"” (2003, 2). In Prophets Facing Backwards (2004) Nanda argues that the postmodern critique of modern science has opened the door for alternative forms of knowledge and these are presented as progressive, reflecting the worldview of hitherto silenced voices. The same arguments are employed by Hindu fundamentalists, creating an unholy synergy between would-be progressive voices in the West and Hindutva intolerance and pseudo-science (see also Nanda 2009, 2016). New Age holism, postcolonial theory, hostility to Enlightenment universalism, radical ecology, Foucaultian discourse analysis, Feyerabend's anarchistic theory of knowledge (1975), and postmodernism make up a complex intellectual patchwork within which outsider judgments about contemporary Indian intellectual debates became highly problematic.

One further complication is the status of linguistics within western science. If we take Saussure's position seriously, that the point of view creates the object, then linguistics cannot serve as an objective comparative science, as a guide to history and prehistory, and as a map of difference. The methodology employed by William Jones, Francis Ellis, and Max Müller was suffused with ideological assumptions about what a language was and its relationship to categories of human identity. From this point of view, nativist objections to the impact of Western linguistic scholarship on Indian society are justified, even if the xenophobic political 
agenda behind these claims is ideologically suspect - from a universalist, liberal point of view. There was no original Dravidian India, nor was there anything like an Aryan invasion, because Aryanism is a construct of the Western identity theorizing implicit in the comparative method. Yet, while Risley's racial narrative of the bas-relief at Sanchi is consigned to the dustbin of history, Aryan and Dravidian linguistics lives on.

There is no easy intellectual position within this complex of problems. The notion of minor universalism inhabits this discomfort zone, perhaps gesturing towards the "enlightened relativism" that Sikka (2011) identifies in Herder.

\section{References}

Beal, Samuel. Some Remarks on the Great Tope at Sânchi. Royal Asiatic Society of Great Britain and Ireland: London, 1870.

Biswas, Saugat Kumar. Autochthon of India and the Aryan invasion. New Delhi: Genuine Publications, 1995.

Bopp, Franz. Über das Conjugationssystem der Sanskritsprache in Vergleichung mit jenem der griechischen, lateinischen, persischen und germanischen Sprache. Frankfurt am Main: in der Andreäischen Buchhandlung, 1816.

Caldwell, Robert. A Comparative Grammar of the Dravidian or South-Indian Family of Languages. London: Harrison, 1856.

Cunningham, Alexander. "Opening of the Topes or Buddhist monuments of Central Asia”. The Journal of the Royal Asiatic Society of Great Britain and Ireland 13 (1852): 108-114.

Dhavalikar, Madhukar Keshav. Monumental Legacy: Sanchi. New Delhi: Oxford University Press, 2003.

Dirks, Nicholas. Castes of Mind: Colonialism and the Making of Modern India. Princeton: Princeton University Press, 2001.

Dyer, Samuel. “An alphabetic language for the Chinese”. The Chinese Repository 4 (1835): 167176.

Ellis, Francis. "Note to Introduction". A Grammar of the Telugu Language. Ed. Duncan Campbell. Madras: College of the Fort St. George, 1816, 1-32.

Evrigenis, Ioannis and Daniel Pellerin. Eds. and transl. Johann Gottfried Herder. Another Philosophy of History and Selected Political Writings. Indianapolis: Hackett, 2014.

Fell, Edward. Description of an Ancient and Remarkable Monument near Bhilsa. Hasingabad, 1819.

Fergusson, James. Tree and Serpent Worship: Illustrations of Mythology and Art in India. London: Allen, 1868.

-. History of Indian and Eastern Architecture, vol. 1. New York: Dodd, Mead, 1899.

Feyerabend, Paul. Against Method: Outline of an Anarchistic Theory of Knowledge. London: New Left Books, 1975.

Fichte, Johann Gottlieb. Reden an die deutsche Nation. Berlin: In der Realschulbuchhandlung, 1808.

Frawley, David. The Myth of the Aryan Invasion of India. Delhi: Voice of India, 2005. 
Goethe, Johann Wolfgang von. Herrmann und Dorothea. Berlin: Vieweg, 1797.

Guha-Thakurta, Tabati. "The production and reproduction of a monument: the many lives of the Sanchi Stupa”. South Asian Studies 29 (2013): 77-109.

Herder, Johann Gottfried von. Auch eine Philosophie der Geschichte zur Bildung der Menschheit. Riga: Hartknoch, 1774.

-. Ideen zur Philosophie der Geschichte der Menschheit, vol. 1. Riga: Hartknoch, 1784.

Heschel, Susannah. The Aryan Jesus: Christian Theologians and the Bible in Nazi Germany.

Princeton, NJ: Princeton University Press, 2008.

Horn, Peter. "The invention of Germany". Acta Academica 42 (2010): 50-62.

Hutton, Christopher. "Writing and speech in Western views of the Chinese language". Critical Zone 2 (2007): 83-106.

-. "Lost in the hall of mirrors: The linguistics of Aryan as a knowledge domain in colonial and postcolonial India". Language, Culture and Society 1 (2019): 8-30.

Jones, Sir William. "Dissertation on the orthography of Asiatick words in Roman letters". The Works of Sir William Jones. London: Robinson and Evans, 1789, 175-228.

-. "On the Hindus, the third anniversary discourse, delivered 2d February, 1786". Asiatick Researches 2 (1798): 365-381.

Kaul, Harikishan. Census of India, 1911: The Punjab, vol. 14. Lahore: Civil and Military Gazette Press, 1912.

Kelly, John. "The 1847 alphabet: an episode of phonotypy”. Towards a History of Phonetics. Eds R. E. Asher and Eugene J. A. Henderson. Edinburgh University Press, 1981, 248-26.

Latour, Bruno. Nous n'avons jamais été modernes: Essai d'anthropologie symétrique. Paris: La Découverte, 1991.

Leopold, Joan. "British applications of the Aryan theory of race to India". The English Historical Review 89 (1974): 578-603.

Maisey, Fredrick. Sanchi and its Remains. London: Kegan, Paul, French, Trübner, 1892.

Malhotra, Rajiv. Being Different: An Indian Challenge to Western Universalism. New Delhi: HarperCollins, 2011.

-. "Author's response: the question of dharmic coherence”. International Journal of Hindu Studies 16 (2013): 369-408.

- and Aravindan Neelakandan. Breaking India: Western Interventions in Dravidian and Dalit Faultlines. Delhi: Amaryllis, 2011.

Marshall, John. A Guide to Sanchi. Calcutta: Superintendent Government Printing, 1918.

Mauro, Tullio de and Lia Formigari. Eds. Leibniz, Humboldt, and the Origins of Comparativism. Proceedings of the international conference, Rome, 25-28 September 1986. Amsterdam: John Benjamins, 1990.

Messling, Markus. Universalität nach dem Universalismus. Über frankophone Literaturen der Gegenwart. Berlin: Matthes \& Seitz, 2019.

Mitra, Debala. Buddhist Monuments. Calcutta: Sahitya Samsad, 1971.

Müller, F. Max. Selected Essays on Language, Mythology and Religion, vol. 2. London: Longmans, Green, 1881 [1874].

Nanda, Meera. Postmodernism and Religious Fundamentalism: A Scientific Rebuttal To Hindu Science. New Delhi: Navayana, 2003.

-. Prophets Facing Backward: Postmodern Critiques of Science and the Hindu Nationalism in India. New Brunswick: Rutgers University Press, 2004.

-. The God Market: How Globalization is making India more Hindu. New Delhi: Random House, 2009. 
-. Science in Saffron: Skeptical Essays on History of Science. New Delhi: Three Essays Collective, 2016.

Nesfield, John Collinson. Brief View of the Caste System of the North-Western Provinces and Oudh. Allahabad: North-Western Provinces and Oudh Government Press, 1885.

Risley, Herbert H. "The race basis of Indian political movements". The Contemporary Review 57 (1890): 742-759.

-. The Tribes and Castes of Bengal, vol. 1. Calcutta: Bengal Secretariat Press, 1901.

-. The People of India. Calcutta: Thacker, Spink, 1908.

Saussure, Ferdinand de. Cours de linguistique Générale. Eds. Charles Bally and Albert Séchehaye. Paris: Payot, 1972 [1916].

Schiller, Friedrich. Was heißt und zu welchem Ende studiert man Universalgeschichte? Antrittsvorlesung in Jena, 26. Mai 1789. Jena: Akademische Buchhandlung, 1789.

Sikka, Sonia. Herder on Humanity and Cultural Difference: Enlightened Relativism. Cambridge: Cambridge University Press, 2011.

Smith, David. "Orientalism and Hinduism". The Blackwell Companion to Hinduism. Ed. Gavin Flood. Oxford: Blackwell, 2003, 45-63.

Talageri, Shrikant. The Aryan Invasion Theory: A Reappraisal. New Delhi: Aditya Prakashan, 1993.

Thapar, Romila. "The theory of Aryan race and India: history and politics". Social Scientist 24 (1996): 3-29.

Theertha, Dharma, Swami. The Menace of Hindu Imperialism. Lahore: Har Bhagwan, 1941.

Trautmann, Thomas. Languages and Nations: the Dravidian proof in colonial Madras. Berkeley: University of California Press, 2006.

Zammito, John, Karl Menges, and Ernest Menze. “Johann Gottfried Herder revisited: the revolution in scholarship in the last quarter century". Journal of the History of Ideas 71 (2010): 661-684. 
